\title{
IV. Notes and News.
}

A new Edict of Asoka.-Hofrath Bühler, in The Academy for May 28th, 1894, gives an account of the discovery, by Dr. A. Führer, near the Nepalese village of Nigliva (thirtyseven miles north-west of Uska, on the North Bengal Railway), of a new pillar edict of Asoka. The pillar is broken, the inscription is on the lower half, and several lines are buried. These latter can only be read after permission, which has been applied for, has been obtained from the Nepalese Government to excavate. But the lines above ground are sufficient to show how important and interesting this new find is. The readable portion says: "When the god-beloved king Piyadassi had been anointed fourteen years he increased the stūpa of Konākamana for the second time, and when he had been anointed .... years he himself came and worshipped it."

The earliest mention of Konāgamana (as he is called in Pali) in printed texts is in the Buddha Vansa (one of the latest books included in the Pitakas), where an account of him as the twenty-third Buddha is given in full. But the seven last Buddhas, of whom he is one, are known to be referred to in inedited portions of the older books, such as the Digha and Majjhima. According to the Buddha Vansa, he was born at Sobhavati and died in the Pabbata Arāma, that is, in the Mountain Pleasaunce, which suggests to Hofrath Bühler the conjecture that we have to look near the site of the newly discovered pillar for the traditional place of his death.

Yuan Thsang tells us how the relics of Kassapa, the twenty-fourth Buddha, were still preserved in his time near Sāvatthi, under a stūpa said to have been built by Asoka; and also of a vihära near the Bo Tree, containing Kassapa's image, and a cankama, where he was supposed to have walked up and down in meditation. But this edict is probably the earliest archæological confirmation we have of the actual preservation, in early Buddhist times, of the 
memory of Konāgamana. The only other evidence of a similar kind is the bas-relief of Konāgamana's Bo Tree figured at pl. xxix of Cunningham's Bharhut Tope. The name in the legend there is spelt with the $g$, not with the $k$.

Mr. S. Arthur Strong, of St. John's College, Cambridge, has been elected to the Chair of Arabic at University College, London, which was vacated by Prof. Rieu's transfer to Cambridge. This appointment will not interfere with Mr. Strong's performance of the duties of librarian to the Duke of Devonshire at Chatsworth. At the same time the Rev. Dr. Robert Bruce was elected to the Chair of Persian, which was also held by Prof. Rieu.

\section{Notices of Books.}

Chülia Kanta Mangala: the Tonsure Ceremony as Perrormen in Siam. By G. E. Gerini. Large 8vo, pp. 186. Bangkok, 1893.

Though dated in 1893, this book by Captain Gerini, of the Royal Military College, Bangkok, has only appeared in 1895. It gives first a slight and not very reliable account of tonsure ceremonies throughout the world, and more especially in India and in Siam. Then, in seven consecutive sections, we have a very detailed and fully illustrated description of the tonsure ceremony as performed now-a-days in Siam, distinguishing throughout the ceremonies observed in the case of boys and girls, and in the case of ordinary people and children of the royal house. The ceremony as performed for Prince Vajravudha, the late Crown Prince of Siam, is detailed at length. There are thirteen full-page illustrations from photographs, and a number of woodcuts. It is curious to observe how the ceremony, which is not a Buddhist one and is not observed in other Buddhist countries, has been adopted and modified in accordance with Buddhist beliefs. The adoption of this 